\title{
Pragmatic Roles of Visuals in ELT Textbooks
}

\section{Chie Kawashima}

Tochigi Technical High School

\section{Reference Data}

Kawashima, C., (2021). Pragmatic roles of visuals in ELT textbooks. In P. Clements, R.Derrah, \& P. Ferguson (Eds.), Communities of teachers \& learners. JALT. https://doi.org/10.37546/ JALTPCP2020-36

This study explored how visual elements are used in textbooks to convey information about pragmatics. The data analysed was visual information collected from beginner level ELT textbooks. The outcome of the study revealed: (a) $4-5$ percent of the visuals provide contextual information associated with speech acts, (b) the majority of these visuals represent speakerhearer power relations and social distance in relation to language use, and (c) these visuals tend to be associated with the speech acts particular to the language use of the speaker-hearer relationship depicted in the visual. In addition, the weakness of visuals as contextual information, which provides the viewers few opportunities to be aware of indirectness or politeness to be used in certain situations, was discussed accordingly. Some practical suggestions were made as to how teachers might supplement contextual information provided with visuals and compensate for their insufficiencies.

本論においては、語用論に関する情報伝達に関して語学学習教材の中で紹介されている視覚的要素の有用性の探査を、

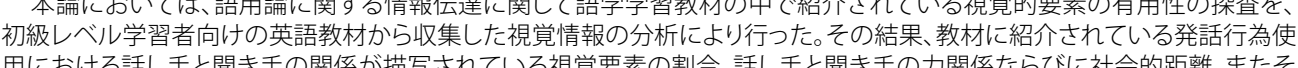
用における話し手と聞き手の関係が描写されている視覚要素の割合、話し手と聞き手の力関係ならびに社会的距離、またそ れに伴う発話行為の種類が明らかになった。したがつて、それぞれの話し手と聞き手の関係において特徴的な言語使用が検 報に関連する言語使用情報の不十分さを補うための教師作成による補助教材の実用性も示唆された。

ppropriate use of speech acts in interpersonal interactions is a crucial aspect of pragmatic competence. In many cases, the speech acts presented in ELT textbooks are introduced and practiced without any speaker-hearer information (Alcon-Safont,
2001; Boxer \& Pickering, 1995; Nguyen, 2011). For novice language learners, visual materials are beneficial to comprehend the texts (Hadley, 2001) and beginner-level ELT textbooks are full of visuals such as photos and graphical illustrations. This study looks at visuals associated with speech acts to determine how each of them conveys contextual information of speech acts to learners by categorising visuals into four types according to speaker-hearer power relations and social distance. Based on the findings, how these visuals can help learners to select language use is discussed.

\section{Literature Review}

Pragmatic Role of Visual Images

Visuals help explain concepts and words thoroughly and precisely. For example, images in advertisements convey attractive dreams or potential future pleasures to viewers, and images appearing in newspapers show the critical moment of an incident or an accident (Van Leeuwen, 2008). Furthermore, Feng and O'Halloran (2012) explored how emotive meaning was represented in comic book drawings by analysing the features of emotions with facial expression semiotic resources including the shape of the mouth, wrinkles, cheeks and eyes, touch, and body orientations. As mentioned above, visual images may play meaningful roles in our everyday communication. They have various functions, such as stimulating the cognitive processes of viewers and inferential abilities for interpreting materials.

\section{Visual Images in Language Textbooks}

The purpose of presenting visuals is one of the crucial factors to determine whether or not the images can facilitate the textbook user's language development. Classification of the visual images in ELT textbooks as "for use" and "for decoration" has been made in a number of studies (Basal et al., 2016; Hill, 2003; Romney, 2012; Romney \& Bell, 2012; Roohani \& Sharifi, 2015). Although many of the textbooks' visuals were classified into the 
'representational' functional category, Basal et al. (2016) pointed out that a still higher number of visuals with decorative functions were problematic. Both Romney and Bell (2012) and Basal et al. (2016) argued that the problem with decorative images is to attract the user's attention for aesthetic reasons with commercial purposes.

In addition, a study by Weninger and Kiss (2012), which examined the interplay of texts, images, and tasks in school EFL textbooks, found the materials inadequate for fostering intercultural competence and global citizenship as their primary goal of presenting the visual images was to extract denotational meanings. The following year, Kiss and Weninger's (2013) study of the interaction of texts and visuals in pedagogical materials noted the lack of tasks with visuals included in ELT resources. Their study adapted Tseng's (2002) triangle way of meaning-making process for interpreting culture, which suggests the role of cultural learning as developing the individual's ability to accept the diversity of other cultural forces. Kiss and Weninger (2013) noticed the significance of using visuals in ELT resources for classroom instruction. In turn, they suggested using text and visuals to generate a critical discussion at the beginning of a lesson based on the learners' spontaneous reactions, where the teacher assists them with "the process of recognition, exploration, and reflection" (Tseng, 2002, p. 16).

\section{Aim of this Study and Research Questions}

The motive for analysing visuals in this study originated in the observation that the speaker-hearer relationship regarding speech acts identified in the ELT textbooks was shown with visual images. For example, the visuals which depict the situation of service encounters are involved in the speech acts of giving offers and requesting, and conventionally indirect forms are used for the most part. As beginner-level ELT textbooks include a number of visual images, I have assumed that these visuals might provide the viewers with contextual information regarding the use of speech acts. Although there have been studies of the pragmatic roles of visual images that were not relevant to pedagogical issues, few studies, if any, have focused on the pragmatic use of visuals in pedagogical materials. In order to determine how the visual elements are used in the textbooks to convey information about pragmatics, the following three research questions were developed:

RQ1. What percentage of visuals in each ELT textbook provides contextual information of speech acts?

RQ2. What are the power relations and social distance of the speaker and hearer in each of the visuals associated with speech acts?
RQ3. What types of speech acts or linguistic forms are involved in each category of the speaker and hearer's power relation and social distance?

\section{Method}

Textbook Selection

In order to compare two different types of ELT textbooks as to inclusion of pragmatic information, international ELT textbooks designed based on a situational syllabus and textbooks used in Japanese high schools, which are developed along with the grammarbased syllabus, were selected. To select the materials to be analysed, emails were sent to the Japan office of five major international publishers to enquire about their topselling international ELT coursebooks at an equivalent level of the first year of upper secondary education (grade 10). Based on their replies, the most widely used materials to develop adult learners' four language skills identified by each publisher were selected (see Appendix A). In addition, seven ELT textbooks for first-year students used in Japanese high schools were also selected for analysis (see Appendix A). This textbook selection was also based on the information about the most widely used textbooks provided by the sales representatives from the major Japanese publishers. The elementary stage levels and the target users vary across the textbooks. Progress, Treasure, and Crown are mainly used in high level academic high schools. Vista and Select are designed for the curriculum implemented in vocational high schools. Vivid and Quest are used in all types of schools.

\section{Selection of Visual Images}

Before analysing the contextual information in each image, the total number of visual images presented in each textbook was counted, and the average number of visuals per page of each textbook was calculated. In this study, all the photos and illustrations were counted as visual images. Those with single frames were counted as one. A four-frame comic strip was counted as four.

Subsequently, the number of visual images which depict a speaker-hearer relationship in each textbook was determined to calculate an overall percentage of visuals that provided contextual information of speech acts. The images were judged to contain contextual information if they include narrative process of ideational meta-function based on Kress and van Leeuwen's (2006) social semiotic theory. Ideational metafunction refers to the representation of the objects, and_narrative process represents participant actions, events, or processes of change. For example, the visual which depicts two human images at the cashier in a shop was judged to include narrative process of 
JALT2020

COMMUNITIES OF
TEACHERS \& LEARNERS ideational meta-function and counted as the visual providing contextual information associated with the speech acts for service encounters.

\section{Categorisation of Visual Images}

To categorise the visual images presented in these ELT textbooks, two instruments were created as shown in Figure 1 and Figure 2 based on Kress and van Leeuwen's (2006) social semiotic theory and Ishihara and Cohen's (2010) use of instruments for field observations or for recording natural conversations.

According to van Leeuwen and Jewitt (2011), meaning is established through the syntactic relations among characters, locations, and things depicted in visuals with social semiotic visual analysis. Each element in Figure 1 provides information to determine the speaker and hearer's power relations, distance, and the intensity of the situation. Intensity refers to the imposition in a request or the severity in an apology as how great the request being made is or how oppressive the mistake or errors was, respectively (Ishihara \& Cohen, 2010; Leech, 2014; Thomas, 1995).

Figure 1

Speaker-hearer Power Relations and Determinants

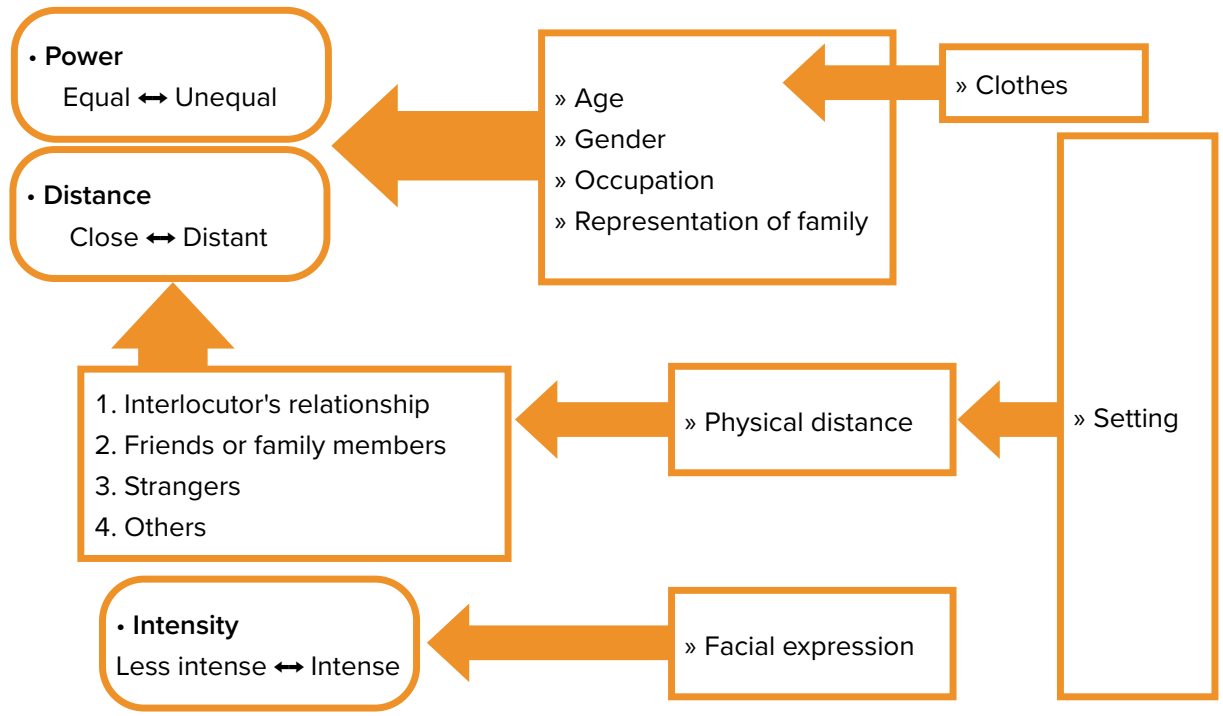

Whether the participants' power is equal or unequal was determined, referring to the categories of power relations summarised by Thomas (1995), as follows:

a. Legitimate power (reward power and coercive power) - power is used by the speaker's virtue of role, age, or status such as employer-employee, parent-child, teacher-student.

b. Referent power - someone who is admired/respected or can be a role model has power over another.

c. Expert power - power is possessed by those with some special knowledge or expertise that the other person needs.

Additionally, the power possessed by someone with a specific right in a specific situation such as a police officer, a security guard and an immigration officer was also taken into consideration.

The classification of distance was made based on the variables as: a) social similarity/ difference, b) frequency of contact, c) length of acquaintance, d) familiarity, or how well people know each other, and e) sense of like-mindedness (Spencer-Oatey, 1996). A number of contextual factors impacting the speaker and hearer's information helped to identify their power relations and social distance of the speaker and hearer. Age, gender, occupation, and representation of family are relevant contextual elements to determine speaker-hearer power relations and distance (Cohen \& Ishihara, 2013; Ishihara \& Cohen, 2010). These elements can also influence how socially and psychologically distant/close people feel to each other (Ishihara \& Cohen, 2010; Spencer-Oatey, 1996). In addition, the participant's clothes can display cultural categorisations representing gender, institutional identity, ethnic identity, or relational identity (Van Leeuwen, 2008). When represented in a visual image, physical distance, or personal space such as public, social, personal, and intimate distance can also provide input on speaker-hearer relationship, although it is culturally specific (Cherry, 2018).

The visuals identified as contextual information of speech acts were categorised into four types according to speaker-hearer power relations and distance based on the diagram in Figure 2. 


\section{JALT2020}

COMMUNITIES OF

Figure 2

Categorisation of Visual Images According to Power Relations and Distance

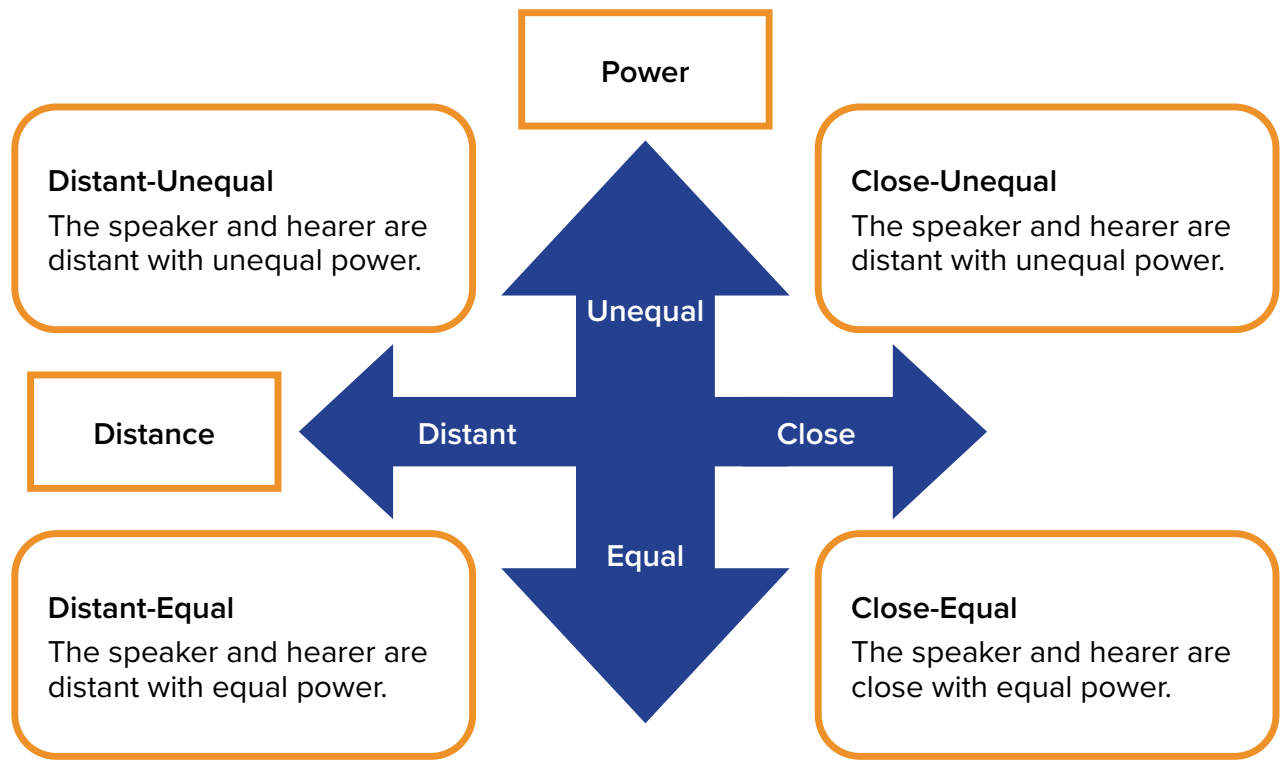

The visuals categorised into distant-unequal included mainly doctor-patient, teacherstudents, and so on. The visuals included in close-unequal depicted mostly parents and children. The speaker and hearer in the visuals categorised into distant-equal were mainly those in service encounters. The visuals which depict friends or family members were typically categorised into close-equal. In cases where the image showed the speaker and hearer's similarity but short length of acquaintance, their distance was determined by physical distance or the setting. Some visuals included the speaker and hearer who were not clearly enough depicted to be categorised into one of these four types, so others was added as a miscellaneous category.

\section{Identification of Speech Acts}

First, speech acts appearing in each textbook were identified using a comprehensive list of speech acts (see Appendix B). This list was created based on combining lists from the previous studies on the speech acts presented in ELT textbooks (Arai, 2005; Nguyen,
2011; Shimizu et al., 2007; Vellenga, 2004). Then, further investigation was undertaken to determine the number of speech act types involved in the visuals related to speakerhearer relationship as categorised into four types in Figure 2. Linguistic forms involved in each of these speech acts were also examined to note whether there were any specific forms related to politeness, directness, or formality specific to the different power relations and distance of the speaker and hearer.

\section{Results}

Visual Images Providing Contextual Information in Each Textbook

The number of visual images which provide contextual information of speech acts in each textbook is displayed in Tables 1 and 2 along with the outcomes of a pageby-page analysis of those included in each textbook. Although the average number of visual images included in the set of international ELT textbooks is far more extensive than those used in Japanese high schools, the average percentage of the images which represent contextual information is only $4-5 \%$ and does not make any noticeable difference between these two sets of textbooks.

Table 1

Visuals Presented in the Set of International ELT Textbooks

\begin{tabular}{lccccc}
\hline Textbook & Interchange & Headway & Cutting & Global & Time \\
\hline Number of pages & 160 & 140 & 128 & 128 & 144 \\
Average number of visuals & 3.1 & 3.5 & 2.6 & 3.4 & 3.3 \\
per page & & & & & \\
Total number of visuals & 499 & 487 & 329 & 438 & 477 \\
$\begin{array}{l}\text { Number of visuals with } \\
\text { contextual information (\%) }\end{array}$ & 35 & 41 & 18 & 3 & 15 \\
& $(7 \%)$ & $(8.4 \%)$ & $(5.5 \%)$ & $(0.6 \%)$ & $(3.1 \%)$ \\
\hline
\end{tabular}

As a whole, a number of visuals which provide contextual information are present in each of international ELT textbooks. Only in Global, however, the number of visuals with contextual information is exceptionally limited although the total number of visuals is far larger than that of Cutting. 
JALT2020

COMMUNITIES OF
TEACHERS \& IEARNERS

Table 2

Visuals Presented in the Set of Japanese High Schools Textbooks

\begin{tabular}{lccccccc}
\hline Textbook & Progress & Treasure & Crown & Vista & Vivid & Select & Quest \\
\hline Number of pages & 243 & 215 & 191 & 135 & 160 & 103 & 138 \\
$\begin{array}{l}\text { Average number of } \\
\text { visuals per page }\end{array}$ & 1.1 & 0.5 & 1.0 & 1.9 & 1.0 & 1.8 & 1.0 \\
$\begin{array}{l}\text { Total number of } \\
\text { visuals }\end{array}$ & 260 & 100 & 184 & 262 & 162 & 189 & 138 \\
$\begin{array}{l}\text { Number of visuals } \\
\text { with contextual }\end{array}$ & 26 & 0 & 2 & 11 & 1 & 11 & 9 \\
information $(\%)$ & $(10.0 \%)$ & & $(1.0 \%)$ & $(4.2 \%)$ & $(0.6 \%)$ & $(5.8 \%)$ & $(6.5 \%)$ \\
\hline
\end{tabular}

As for the set of textbooks used in Japanese high schools, the percentage of visuals with contextual information is uneven across the textbooks. In Progress, as many as 26 visuals, which account for 10 percent of the total number of visuals, represent contextual information while the number of visuals with contextual information is very limited in the remaining textbooks. In Treasure, these visuals are completely absent.

\section{Speaker-Hearer Power Relations and Social Distance}

Most of the visuals presented across the textbooks were categorised into distantequal or close-equal, where speaker-hearer power relations are equal. As for the social distance, nearly half of the visuals included in the set of international ELT textbooks were categorised into close-unequal or close-equal. Likewise, 60 percent of the visuals in those used in Japanese high schools can be classified into close-unequal or close-equal. Therefore, most of the visuals included across the textbooks represent equal speakerhearer power relations regardless of their social distance.

The visuals which depict the speaker and hearers at service encounters as well as those who are asking/giving directions were categorised into distant-equal. This type of visuals accounts for 41 percent of those with contextual information across the international ELT textbooks and 22 percent across the textbooks used in Japanese high schools. Finally, close-equal visuals, where friends, couples and siblings are depicted, make up over 40 percent across both sets of textbooks.
The visuals categorised into distant-unequal account for nine percent across international ELT textbooks and 18 percent across the textbooks used in Japanese high schools. As for detailed speaker-hearer relationships, teacher-student relationship is depicted in as many as 13 out of 21 visuals. Concurrently that of doctor-patient can be categorised into this type. Moreover, the visuals depicting an immigration officer and a passenger who is crossing the border at the passport control were also classified into distant-unequal, as well as the one with a security guard and a group of audience at the entrance of a football stadium. Close-unequal visuals, which account for four percent across the international ELT textbooks and 13 percent across the textbooks used in Japanese high schools, all depict family members like parent-child. Additionally, five visuals in Headway were impossible to categorise into one of these four types of power relations and social distance due to minimal speaker and hearer's information depicted and were categorised into others.

Linguistic Forms Associated Concerning Speaker-Hearer Power Relations and Distance

The range of speech acts involved in each type of visuals are shown in Tables 3 and 4. Although the total number of samples presented in the set of international ELT textbooks is larger, the range of speech acts in the visuals with contextual information in the Japanese high school textbooks is slightly more expansive than the international ELT textbooks, except for distant-equal relationships. As a whole, a wider range of speech acts is associated with the visuals in distant-equal and close-equal, while the visuals in distantunequal and close-unequal involve a relatively narrow range of speech acts. Therefore, the range of speech acts associated with visuals might be tied up with the number of those categorized into each group. 
Table 3

Speech Acts Expressed in Visuals in International ELT Textbooks

\begin{tabular}{ll}
\hline Type (Number of Visuals) & \multicolumn{1}{c}{ Speech Acts } \\
\hline Distant-Unequal (10) & $\begin{array}{l}\text { Prohibiting, Requesting, Thanking, Greeting, Leave- } \\
\text { taking, Giving orders, Expressing sympathy [7] }\end{array}$
\end{tabular}

Close-Unequal (4) Suggesting proposals, Asking for permission, Requesting, Refusing requesting, Greeting, Giving orders, Apologising, Making accusations [9]

Distant-Equal (46) Giving advice, Giving offers, Refusing offers, Requesting, Refusing requests, Apologising, Complimenting, Responding to compliments, Thanking, Responding to thanking, Greeting, Leave-taking, Giving orders, Expressing opinions, Asking directions, Giving directions, Expressing sympathy [17]

Close-Equal (47)

Giving advice, Accepting advice, Giving offers, Accepting offers, Refusing offers, Suggesting proposals, Accepting proposals, Refusing proposals, Apologising, Responding to apology, Complimenting, Responding to compliments, Thanking, Greeting, Leave-taking, Giving orders, Agreeing, Assessing, Encouraging, Celebrating, Exclaiming, Expressing sympathy [21]

Others (5) Apologising, Complimenting, Responding to compliments, Thanking, Leave-taking [5]

Note: The number of speech act types which involve visuals in each type of speaker-hearer relationship is shown in brackets.
Table 4

Speech Acts in Visuals in Japanese High School Textbooks

\begin{tabular}{|c|c|}
\hline Type (Number of Visuals) & Speech Acts \\
\hline Distant-Unequal (11) & $\begin{array}{l}\text { Giving advice, Giving offers, Suggesting proposals, } \\
\text { Asking for permission, Giving permission, Prohibiting, } \\
\text { Requesting, Complimenting, Greeting, Leave-taking, } \\
\text { Giving orders, Assessing [12] }\end{array}$ \\
\hline Close-Unequal (8) & $\begin{array}{l}\text { Giving advice, Asking for permission, Requesting, } \\
\text { Thanking, Giving orders, Expressing opinions, Assessing, } \\
\text { Exclaiming, Responding to good news [9] }\end{array}$ \\
\hline Distant-Equal (13) & $\begin{array}{l}\text { Giving advice, Accepting advice, Giving offers, Accepting } \\
\text { offers, Requesting, Thanking, Responding to thanking, } \\
\text { Greeting, Asking directions, Giving directions, Assessing } \\
\text { [11] }\end{array}$ \\
\hline Close-Equal (28) & $\begin{array}{l}\text { Asking for advice, Giving advice, Suggesting proposals, } \\
\text { Accepting proposals, Asking for permission, Giving } \\
\text { permission, Requesting, Apologising, Complimenting, } \\
\text { Responding to compliments, Thanking, Responding to } \\
\text { thanking, Greeting, Leave-taking, Giving orders, Asking } \\
\text { for opinions, Expressing opinions, Agreeing, Disagreeing, } \\
\text { Assessing, Exclaiming, Expressing sympathy [22] }\end{array}$ \\
\hline
\end{tabular}

Note: The number of speech act types which involve visuals in each type of speaker-hearer relationship is shown in brackets

The categorised visuals tend to be associated with the speech acts specific to the language use of the speaker-hearer relationships depicted in these visuals. The speakerhearer relationship in many of distant-equal visuals is relevant to service encounters. The use of the speech act of requesting with conventionally indirect forms, e.g., "Can you ...?" or "Can I...?" as a fixed expression in service encounters, was observed. In Headway the linguistic form of "I would like ..." is highlighted as a polite request. In Cutting, on the other hand, most of the visuals associated with requesting are presented with another fixed expression of "N, please." Moreover, the visuals associated with the speech act of giving orders were mainly categorized into distant-unequal. Imperatives are mostly used 
by a teacher as a part of classroom English with distant-unequal visuals. Likewise, the speech act of giving orders is typically employed by someone with a specific right, such as an immigration officer at the passport control and a security guard in a football stadium depicted in distant-unequal visuals.

\section{Discussion}

Although the page-by-page analysis of each textbook revealed inclusion of a large number of visual images, the percentage of those which are associated with speech acts is very small. Nevertheless, a wide range of speech acts is associated with these visuals across the textbooks. There is a pattern in involving speech acts in the visuals categorised into each type of speaker-hearer relationship.

The current study noted that the speaker and hearer's social role may have an impact on language use involved in the visuals categorised into distant-equal and distant-unequal. The speech act of requesting is typically present with distant-equal visuals in service encounters in these textbooks. Although this speech act is politeness sensitive (Leech, 2014), linguistic forms introduced along with these visuals are conventionally indirect or imperatives + please for the most part. Spencer-Ottay (1996) regards the role relationship used for the dyads in service encounters as equal since the service givers' right to receive payment and obligation to provide good service and service receivers' right to complain about poor service and obligation to pay are balanced out. As for language use, Gagne (2018) observed principal use of conventionally indirect request for product request in the authentic data. Therefore, direct or conventionally indirect language use may predominantly appear along with the visuals of distant-equal as far as the speaker and hearer's social role is concerned.

Indirect language use with distant-unequal visuals is entirely absent across the textbooks, and the language use with these visuals is typically direct. Although indirect use of language is governed by the factors represented in unequal power relations with social distance between the speaker and hearer along with rights and obligations (Thomas, 1995), only the language use of those with higher power is highlighted in these textbooks. As Taguchi and Rover (2017) describe, speakers' power is firmly controlled by the context and social roles rather than intrinsic to individuals. It may be necessary to be aware that the speaker has power over the hearer in a particular context while their power relation may be converted in another context with different social roles. In the case of the utterance of "Move this vehicle" produced by a police officer, this imperative is made in the capacity of a police officer although $\mathrm{s} / \mathrm{he}$ might choose indirect language use to say the same thing in his/her private capacity (Thomas, 1995). If the language use of those with lower power was also highlighted, indirect/polite language use might be introduced along with these visuals. In contrast, language use of the speaker and hearer in both close-unequal and close-equal visuals is not influenced by their social roles.

Overall, indirect use of language associated with these visuals is almost absent. Although it is preferable to be indirect, polite, or formal due to a number of factors in certain circumstances, almost all the linguistic forms of the speech acts associated with the visuals identified in this study are direct or conventionally indirect. Therefore, the contexts for language use are limited to those where indirect/polite language use is not required. Perhaps, the syntax structures of dialogues were simplified due to the necessity to match the language use to the learners' proficiency level, or keep the linguistic focus of the unit and important aspect of social interaction is neglected (Nguyen \& Ishitobi, 2012).

\section{Conclusion}

Although only 4-5 percent of all the visuals included in the ELT textbooks were analysed in this study, these visuals are associated with a number of different speech act types. Most of these visuals were categorised into distant-equal and close-equal. The result of the categorisation of these visuals uncovered that language use employed in a specific situation is closely related to the speaker and hearer's social roles.

Although few visuals which could provide an opportunity to use indirect/polite forms were included in the textbooks, visual images may still help textbook users with selecting language use according to the circumstances and speaker-hearer relationship. As Kiss and Weninger (2013) noted the significance of visuals presented in ELT materials for classroom instruction and the potentials to enhance learners' cultural awareness through their critical discussion, visual images may also play a key role for pragmatic language instruction.

The activities to enhance the learners' cultural awareness using visual images proposed by Kiss and Weninger (2013) could be adapted to pragmatic input with visuals, where learners can discuss the language use in relation to speaker-hearer power relations and social distance. As Ishihara and Cohen (2010) suggested, an awareness-raising approach along with explicit instruction according to a list of tasks to analyse and identify language use both with linguistic and sociocultural focus may help learners notice the significance of selecting language use in contexts. Likewise, the necessity of raising awareness through discussion about language use according to speaker-hearer 
relationship has been emphsised (Eslami \& McLeod, 2010; Rinnert \& Iwai, 2010; Yates \& Springall, 2010). Therefore, visual images, as such, can be used for pragmatic input and practice raising learners' awareness of appropriate language use according to the context with a teacher's modification.

\section{Bio Data}

Chie Kawashima is an English teacher at Tochigi Prefectural Tochigi Technical High School. She is currently writing a doctoral thesis on pragmatic information presented in ELT materials. <kawashimachie@hotmail.com>

\section{References}

Alcon, E., \& Safont, P. (2001). Occurrence of exhorative speech acts in ELT materials and natura speech data: A focus on request, suggestion and advice realisation strategies. Studies in English Language and Linguistics, 3, 5-22.

Arai, T. (2005). Teaching politeness in lower secondary schools in Japan: Text analysis of politeness. Proceedings of the 10th conference of Pan-Pacific association of applied linguistics, 15-30.

Basal, A., Celen, K. M., Kaya, T., \& Bogaz, S. N. (2016). An investigation into illustrations in English course books in a Turkish context. International Electronic Journal of Elementary Education, 8(3), 525-236. Retrieved from https://www.iejee.com/index.php/lEJEE/article/view/129

Boxer, D., \& Pickering, L. (1995). Problems in the presentation of speech acts in ELT materials: the case of complaints. ELT Journal, 49(1), 44-58. https://doi.org/10.1093/elt/49.1.44

Cherry, K. (2018). Understanding body language and facial expressions Retrieved from https:// www/verywellmind.com/understand-body-language-and-facial-expressions-4147228

Cohen, A., \& Ishihara, N. (2013). Pragmatics. In B. Tomlinson (Ed.), Applied linguistics and materials development (pp. 113-126). Bloomsbury.

Eslami, Z. R., \& McLeod, K. D. (2010). It's 8 o'clock in the morning. Are you watching television? Teaching indirect requests. In D. Tatsuki \& N. R. Houck (Eds.), Pragmatics: Teaching speech acts (pp. 29-28). Teachers of English to Speakers of Other Languages.

Feng, D. Z., \& O'Halloran. (2012). Representing emotive meaning in visual images: A social semiotic approach. Journal of Pragmatics, 44, 2067-2084. https://doi.org/10.1016/j.pragma.2012.10.003

Gagne, C. (2018). Indirectness and entitlement in product requests in British service encounters. Journal of Pragmatics, 133, 1-14. https://doi.org/10.1016/j.pragma.2018.05.015

Hadley, A. O. (2001). Teaching language in context. Heinle \& Heinle.

Hill, D. A. (2003). The visual elements in EFL coursebooks. In B. Tomlinson (Ed.), Developing materials for language teaching (pp. 157-166). Continuum. https://doi. org/10.5040/9781474211826.ch-010
Ishihara, N., \& Cohen, A. (2010). Teaching and learning pragmatics: Where language and culture meet. Pearson. https://doi.org/10.4324/9781315833842

Kiss, T., \& Weninger, C. (2013). A semiotic exploration of cultural potential in EFL textbooks. Malaysian Journal of ELT Research, 9(1), 19-28.

Kress, G., \& van Leeuwen, T. (2006). Reading images: The grammar of visual design. Routledge. https://doi.org/10.4324/9780203619728

Leech, G. (2014). The pragmatics and politeness. Oxford University Press.

https://doi.org/10.1093/acprof:oso/9780195341386.001.0001

Nguyen, M. T. T. (2011). Learning to communicate in a globalized world: To what extent do school textbooks facilitate the development of intercultural pragmatic competence? RELC Journal, 42(1), 17-30. https://doi.org/10.1177/0033688210390265

Nguyen, H. T., \& Ishitobi, N. (2012). Ordering fast food: Service encounters in real-life interaction and in textbook dialogues. JALT Journal, 34(2), 151-185 https://doi.org/10.37546/jaltjj34.2-2.

Rinnert, C., \& Iwai, C. (2010). I want you to help me: Learning to soften English requests. In D. Tatsuki \& N. R. Houck (Eds.), Pragmatics: Teaching speech acts (pp. 29-46). Teachers of English to Speakers of Other Languages.

Romney, C. (2012). Images in ELT textbooks: Are they just decoration? In A. Stewart \& N. Sonoda (Eds.), JALT 2011 Conference Proceedings (pp. 392-398). JALT. Retrieved from https://jaltpublications.org/files/pdf-article/jalt2011-038.pdf

Romney, C., \& Bell, L. (2012). The role of graphics in business English. In R. Chartrand \& E. Skier (Eds.), The 2011 Pan-SIG Conference Proceedings (pp. 210-219). JALT. Retrieved from https:// pansig.org/publications/2011/pansig2011proceedings.pdf

Roohani, A., \& Sharifi, M. (2015). Evaluating visual elements in two EFL textbooks. Indonesian Journal of Applied Linguistics, 4(2), 68-77. https://doi.org/10.17509/ijal.v4i2.684

Spencer-Ottay, H. (1996). Reconsidering power and distance. Journal of Pragmatics, 26, 1-24. https://doi.org/10.1016/0378-2166(95)00047-x

Shimizu, T., Fukasawa, E., \& Yonekura, S. (2007). Introductions and practices of speech acts in Oral Communication 1 textbooks: From a viewpoint of interlanguage pragmatics. Sophia Linguistica, 55, 143-163.

Taguchi, N., \& Rover, C. (2017). Second language pragmatics. Oxford University Press.

Thomas, J. (1995). Meaning in interaction: An introduction to pragmatics. Longman

Tseng, Y. H. (2002). A lesson in culture. ELT Journal, 56(1), 11-21. https://doi.org/10.1093/ elt/56.1.11

van Leeuwen, T. (2008). Discourse and practice: New tools for critical discourse analysis. Oxford University Press. 


\section{JALT2020}

COMMUNITIES OF
TEACHERS \& IEARNERS
Kawashima: Pragmatic Roles of Visuals in ELT Textbooks

van Leeuwen, T., \& Jewitt, C. (2011). Introduction. In T. Van Leeuwen \& C. Jewitt (Eds.), The handbook of visual analysis (pp. 1-9). SAGE Publication.

Vellenga, H. (2004). Learning pragmatics from ESL \& EFL textbooks: How likely? Retrieved from http://tesl-ej.org/ej30/a3.html

Weninger, C., \& Kiss, T. (2012). Culture in English as a foreign language (EFL) textbooks: A semiotic approach. TESOL Quarterly, 47(4), 694-716. https://doi.org/10.1002/tesq.87

Yates, L., \& Springall, J. (2010). Soften up! Successful requests in the workplace. In D. Tatsuki \& N. R. Houck (Eds.), Pragmatics: Teaching speech acts (pp. 67-86). Teachers of English to Speakers of Other Languages.

\section{Appendix A}

Textbooks Used for This Study

International ELT Textbooks

- Interchange Intro (Cambridge University Press 2013)

- American Headway Starter (Oxford University Press 2010)

- Cutting Edge Starter (Pearson Education 2012)

- Global Beginner Course Book (MacMillan 2010)

- Time Zones 1 (Cengage Learning 2010)

Textbooks Used in Japanese High Schools

- Progress IN ENGLISH 21 BOOK 3 (Edec 2012)

- New Treasure English Series Stage 3 (Z-kai 2003)

- Crown English Communication I (Sanseido 2013)

- Vista English Communication I (Sanseido 2013)

- Vivid English Communication I (Daiichi Gakushusha 2013)

- Select English Expression I (Sanseido 2013)

- Vision Quest English Expression I (Keirinkan 2013)
List of Speech Acts

\begin{tabular}{|c|c|}
\hline Speech Act Categories & Speech Acts \\
\hline \multirow[t]{3}{*}{ 1. Advice } & Asking for advice \\
\hline & Giving advice \\
\hline & Accepting advice \\
\hline \multirow[t]{3}{*}{ 2. Offers } & Giving offers \\
\hline & Accepting offers \\
\hline & Refusing offers \\
\hline \multirow[t]{3}{*}{ 3. Proposals } & Suggesting proposals \\
\hline & Accepting proposals \\
\hline & Refusing proposals \\
\hline \multirow[t]{2}{*}{ 4. Permission } & Asking for permissions \\
\hline & Giving permissions \\
\hline 5. Prohibition & Prohibiting \\
\hline \multirow[t]{2}{*}{ 6. Requests } & Requesting \\
\hline & Refusing requesting \\
\hline \multirow[t]{2}{*}{ 7. Apology } & Apologising \\
\hline & Responding to apology \\
\hline \multirow[t]{2}{*}{ 8. Compliments } & Complimenting \\
\hline & Responding to compliments \\
\hline 9. Accusation & Giving accusations \\
\hline \multirow[t]{2}{*}{ 10. Thanks } & Thanking \\
\hline & Responding to thanking \\
\hline \multirow[t]{2}{*}{ 11. Greetings } & Greeting \\
\hline & Leave-taking \\
\hline 12. Orders & Giving orders \\
\hline
\end{tabular}


JALT2020

TEACHERS \& LEARNERS

Kawashima: Pragmatic Roles of Visuals in ELT Textbooks

\begin{tabular}{|l|l|}
\hline Speech Act Categories & \multicolumn{1}{|c|}{ Speech Acts } \\
\hline \multirow{4}{*}{ 13. Opinions } & Asking for opinions \\
\cline { 2 - 2 } & Expressing opinions \\
\cline { 2 - 2 } & Agreeing \\
\cline { 2 - 2 } & Disagreeing \\
\cline { 2 - 2 } & Agreeing and disagreeing \\
\hline \multirow{2}{*}{ 14. Directions } & Asking directions \\
\cline { 2 - 2 } & Giving directions \\
\hline 15. Assessment & Assessing \\
\hline 16. Celebration & Celebrating \\
\hline 17. Encouragement & Encouraging \\
\hline 18. Exclamation & Exclaiming \\
\hline 19. Sympathy & Expressing sympathy \\
\hline $\begin{array}{l}\text { 20. Responses to good } \\
\text { news }\end{array}$ & Responding to good news \\
\hline
\end{tabular}

Note: This list was created based on the studies of Arai (2005), Nguyen (2011), Shimizu et al. (2007) and Vellenga (2004) 